\title{
Estimation of Myocardial Infarct Size from Plasma Myoglobin or Fatty Acid-Binding Protein. Influence of Renal Function
}

\author{
K. Will H. Wodzig', Johannes A. Kragten ${ }^{2}$, Wim Th. Hermens ${ }^{3}$, Jan F. C. Glatz ${ }^{3}$ and Marja P. van Dieijen-Visser ${ }^{1}$
}

1 Department of Clinical Chemistry, Academic Hospital, Maastricht, The Netherlands

${ }^{2}$ Department of Cardiology, Ziekenhuis De Wever en Gregorius, Heerlen, The Netherlands

${ }^{3}$ Cardiovascular Research Institute Maastricht, Maastricht University, Maastricht, The Netherlands

Summary: Myoglobin $\left(M_{\mathrm{r}} 18000\right)$ and fatty acid-binding protein $\left(M_{\mathrm{r}} 15000\right)$, are low molecular mass cytoplasmic proteins that are considered useful biochemical markers for early detection or exclusion of acute myocardial infarction, and also for early estimation of infarct size. As each of these proteins shows renal clearance, we studied the influence of renal function on the estimation of infarct size from their plasma concentration curves. For this, infarct size estimated from plasma myoglobin or fatty acid-binding protein release curves was compared with that estimated with the established infarct size markers hydroxybutyrate dehydrogenase and creatine kinase, which are not influenced by changes in renal function. The discordance between infarct size estimates was related to renal function.

Creatine kinase (EC 2.7.3.2), hydroxybutyrate dehydrogenase (EC 1.1.1.27), myoglobin, fatty acid-binding protein and creatinine were assayed serially in plasma samples obtained frequently and for at least 72 hours after the start of thrombolytic therapy in 20 patients with acute myocardial infarction. Cumulative release of the different cardiac markers was calculated by using a two-compartment model for circulating proteins. Mean tissue contents of $156 \mathrm{U} / \mathrm{g}$ for hydroxybutyrate dehydrogenase, $2163 \mathrm{U} / \mathrm{g}$ for creatine kinase, $2.79 \mathrm{mg} / \mathrm{g}$ for myoglobin and $0.57 \mathrm{mg} / \mathrm{g}$ wet weight for fatty acid-binding protein, were used to express infarct size in gram-equivalents of healthy myocardium per litre of plasma (g-eq/1). Mean plasma creatinine was obtained by averaging the creatinine concentrations measured in all plasma samples taken during the first 24 hours after acute myocardial infarction.

A relation was found between the mean plasma creatinine concentration during the first 24 hours after acute myocardial infarction and the discordance between infarct size estimated from cumulative hydroxybutyrate dehydrogenase release, compared to infarct size estimated from cumulative myoglobin or fatty acid-binding protein release. For patients with mean plasma creatinine concentrations within the reference interval for creatinine (group $1, n=15$ ) a good agreement was found between infarct size estimated from myoglobin or fatty acid-binding protein plasma curves and that estimated with either hydroxybutyrate dehydrogenase or creatine kinase. However, for patients with a mean creatinine concentration above the upper reference limit (group 2, $n=5$ ), infarct size calculated from plasma myoglobin or fatty acid-binding protein release curves was markedly overestimated, especially for larger infarcts.

Estimation of infarct size from serial plasma myoglobin or fatty acid-binding protein concentrations is possible in the first 24 hours after the onset of symptoms, but only in patients with normal renal function, as estimated from plasma creatinine concentrations.

\section{Introduction}

The serial measurement of cardiac proteins in blood plasma is frequently used for diagnosing acute myocardial infarction and also for infarct size estimation. Since the introduction of thrombolytic treatment the necessity for earlier detection or exclusion of acute myocardial infarction has become extremely important. Apart from early detection of acute myocardial infarction, an earlier estimation of infarct size would be of value for determining patient prognosis in an earlier stage, or for evaluating in clinical studies the effect of therapeutic interventions on infarct size.
Myoglobin is a low molecular mass $\left(M_{\mathrm{r}} 18000\right)$ nonenzymatic protein, abundantly present in the cytoplasm of both cardiac and skeletal muscle cells $(1,2)$. Upon muscle cell damage, myoglobin is rapidly released into plasma and is considered a useful marker especially for early detection of myocardial infarction $(3-5)$, for detection of reinfarction $(2,3)$ and for monitoring of cardiac reperfusion after thrombolytic therapy (6-8).

Another small cardiac protein, heart-type fatty acidbinding protein $\left(M_{\mathrm{r}} 15000\right)$ has also been proposed as an early marker for acute myocardial infarction (9-11). Fatty acid-binding protein is a cytoplasmic protein that 
serves as an intracellular carrier for fatty acids $(12,13)$. Compared with high molecular mass cytoplasmic enzymes such as hydroxybutyrate dehydrogenase (EC 1.1.1.27; $M_{\mathrm{r}}=136000$ ) or creatine kinase (EC 2.7.3.2; $M_{\mathrm{r}}=80000$ ), myoglobin and fatty acid-binding protein are more rapidly released into plasma, resulting in detectable increases in plasma as early as $2 \mathrm{~h}$ after the onset of coronary occlusion $(6,11)$. Although myoglobin and fatty acid-binding protein are both present in heart as well as skeletal muscle cells, their different contents in these tissues and simultaneous release upon muscle injury allows the plasma ratio of myoglobin/fatty acidbinding protein to be used to discriminate myocardial (ratio $=4-6$ ) from skeletal muscle injury (ratio $=20-$ 70) $(14,15)$.

For quantitative assessment of myocardial tissue damage from the plasma myoglobin or fatty acid-binding protein curve, the calculated cumulative release per liter plasma has to be divided by myoglobin or fatty acid-binding protein content per gram wet weight of tissue, so that myocardial injury can be expressed in gram equivalents of healthy myocardium per liter plasma (infarct size). To do so, it is required that the variations in cardiac tissue content among individuals be small. We demonstrated that the inter-individual variations in cardiac tissue content of fatty acid-binding protein and hydroxybutyrate dehydrogenase (about $15 \%$ ) are smaller compared to the inter-individual variation of myoglobin content (about 25\%) (16).

In a recent study on the estimation of infarct size from plasma fatty acid-binding protein concentrations it was shown that the cumulative fatty acid-binding protein release, expressed as gram equivalents of healthy myocardium per liter plasma, yielded a comparable although slightly higher infarct size when estimated from fatty acid-binding protein compared to that estimated from hydroxybutyrate dehydrogenase plasma curves (11). For myoglobin, it has been demonstrated that plasma levels are inversely related to the glomerular filtration rate $(r=0.62)$ and linearly related to serum creatinine $(r=0.63)$ in patients with renal disease (17). Fatty acidbinding protein elevated plasma levels have also been found in the case of renal insufficiency $(14,18)$. As a consequence, individual differences in renal function, or impairment of renal function after acute myocardial infarction, may complicate the quantitative use of myoglobin and also fatty acid-binding protein.

Therefore, the aims of the present study were

(1) to compare infarct size, estimated from plasma release curves of low molecular mass markers like myoglobin and fatty acid-binding protein, with infarct size estimated with the established infarct size markers hydroxybutyrate dehydrogenase and creatine kinase, and
(2) to examine the influence of changes in renal clearance of myoglobin or fatty acid-binding protein on infarct size estimation.

For the latter the discordance between infarct size estimated from hydroxybutyrate dehydrogenase release, compared to infarct size estimated from myoglobin or fatty acid-binding protein release $\left(\mathrm{Q}_{\text {myoglobin }} / \mathrm{Q}_{\mathrm{HBDH}}\right.$ or $\left.\mathrm{Q}_{\mathrm{FABP}} / \mathrm{Q}_{\mathrm{HBDH}}\right)$, was related to the mean plasma creatinine concentration during the first 24 hours after acute myocardial infarction.

\section{Patients and Methods}

Patients

Patients (17 men and 3 women, tab. 1) presented at the Department of Cardiology of the Hospital De Wever en Gregorius in Heerlen with chest pain and ST segment elevation typical of acute myocardial infarction within 6 hours after the onset of symptoms, were treated with thrombolytic therapy. First, $160 \mathrm{mg}$ of acetylsalicylic acid (aspirin) was given (unless already given by a general practitioner or ambulance nurses), followed by thrombolytic therapy, which consisted of 1.5 million units of streptokinase, given by infusion in $40 \mathrm{~min}$. Four hours after starting thrombolytic therapy heparin was given, 12500 units subcutaneous, by every 12 hours, for 5 days. All procedures followed were approved by the Medical Ethical Committee of the Hospital.

All patients included had given informed consent. Their mean age was $61 \pm 7.7$ years (mean $\pm S D$, median 60 and range 49-78 years) and the mean treatment delay was $2.1 \pm 1.2 \mathrm{~h}$ (mean $\pm \mathrm{SD}$, median 1.8 and range $0.7-5.3 \mathrm{~h}$ ). Patients with increased risk of bleeding, previous coronary bypass surgery or Q-wave indicated infarction in the same location, severe hepatic disease, or inability to give informed consent were excluded from the study.

Venous blood samples of $10 \mathrm{ml}$ were obtained immediately before starting thrombolytic therapy, and 1, 2, 3, 4, 5, 6, 8, 10, 14, 18, 22, $28,34,46,58$, and $70 \mathrm{~h}$ later. Exact sampling times were recorded and expressed as time after the onset of symptoms. Most samples were taken from indwelling catheters and care was taken to prevent haemolysis. Contamination with infused solutions was prevented by using a second catheter for infusion purposes. Blood was collected in pre-distributed and labelled tubes, containing dry heparin to prevent clotting, and was taken to the laboratory immediately. Plasma samples, obtained after routine centrifugation, were stored at $-70^{\circ} \mathrm{C}$ until analysis.

\section{Assays}

Activities of creatine kinase and hydroxybutyrate dehydrogenase were measured spectrophotometrically at $37^{\circ} \mathrm{C}$ using a centrifugal analyzer (Cobas Bio System, Hoffmann La Roche, Mijdrecht, The Netherlands). Commercially available testkits were used for creatine kinase (CK-N-acetylcysteine, International Federation of Clinical Chemistry [IFCC] recommendation, Unimate 3 Roche, art no. 0736473) and hydroxybutyrate dehydrogenase (Deutsche Gesellschaft für Klinische Chemie [DGKC] recommendation, optimized test from Boehringer, art no. 1442 589, Almere, The Netherlands). The hydroxybutyrate dehydrogenase test is based on preferential catalytic activity of the myocardial isoforms 1 and 2 of lactate dehydrogenase toward $\alpha$-ketobutyrate instead of pyruvate, the natural substrate of lactate dehydrogenase. Activities were determined at $37^{\circ} \mathrm{C}$ and were expressed in micromoles of substrate converted per minute (U), either per liter of plasma (U/l) or per gram wet weight of tissue $(\mathrm{U} / \mathrm{g})$.

Myoglobin was measured with a turbidimetric immunoassay, using the method of Delanghe et al. (19) (Turbiquant immunoassay, code OWNL, Behring, Hoechst Holland, Amsterdam, The Netherlands) on a TurbiTimer analyzer (Behring, Hoechst Holland). Dilutions of 
plasma and tissue samples were made in saline $(9 \mathrm{~g} / 1 \mathrm{NaCl})$. The detection limit of the method was $50 \mu \mathrm{g} / \mathrm{l}$ and the measuring range $50-650 \mu \mathrm{g} / \mathrm{l}$. Internal quality control was performed using the human Apolipoprotein Control Serum CHD (Behring, OUPH 06/07, lotno. 063617, assigned value $95(81-109 \mu \mathrm{g} / \mathrm{l})$. Measurement of this control serum on 22 successive days resulted in a mean concentration of $97.4 \mu \mathrm{g} / 1$ with $4.8 \%$ variation.

Fatty acid-binding protein was measured by a direct (one-step) non-competitive immunosorbent assay of the antigen capture type (sandwich ELISA) as described by Wodzig et al. (20). Samples were diluted with phosphate buffered saline $(\mathrm{pH} 7.4)$ containing $1 \mathrm{~g} / 1$ bovine serum albumin and $0.5 \mathrm{~g} / 1$ Tween-20. The detection limit of the assay was $0.2 \mu \mathrm{g} / \mathrm{l}$. The recovery (mean $\pm \mathrm{SD}$ ) of purified human heart fatty acid-binding protein added in various quantities to control human plasma was $97 \pm 5 \%(n=12)$ in the intra- and inter-assay coefficient of variation were respectively $6.5 \%$ and $11 \%$.

Creatinine was analyzed on a Beckman Synchron CX-7 system with Beckman reagents (testkit CREA 442760, Beckman Instruments Inc., Mijdrecht, The Netherlands). The method is based on a modified Jaffe method. In the reaction, creatinine combines with picrate in an alkaline solution to form a creatinine-picrate complex. The system monitors the change in absorbance at $520 \mathrm{~nm}$. Reference values were $71-110 \mu \mathrm{mol} / 1$ in men, and in women 53-97 $\mu \mathrm{mol} / \mathrm{l}$.

\section{Calculation of cumulative protein release into plasma}

The cumulative release of enzyme activity per liter of plasma from the onset of acute myocardial infarction $(t=0)$ up to time $t, Q(t)$, was calculated with the following expression for a two-compartment model:

$$
\begin{aligned}
Q(t)= & C(t)+\operatorname{TER} \int_{0}^{t} \exp [-\operatorname{ERR}(t-\tau)] C(\tau) d \tau \\
& + \text { FCR } \int_{0}^{t} C(\tau) d \tau .
\end{aligned}
$$

The three terms are the protein concentration in plasma, the extravasated protein concentration and the concentration eliminated from plasma, all three expressed per liter of plasma. $C(t)$ is the plasma enzyme activity or protein concentration at time $t$, corrected by subtraction of the normal steady-state values $C_{s}$. The fractional rate constants are for transcapillary escape (TER), extravascular return (ERR) and catabolism (FCR) of activity. This two-compartment model has been validated in the $\operatorname{dog}(21,22)$. Values for hydroxybutyrate dehydrogenase (HBDH) and creatine kinase (CK) estimated in man are (23):

$$
\begin{aligned}
& \mathrm{FCR}_{\mathrm{HBDH}}=0.015 \mathrm{~h}^{-1}, \quad \mathrm{FCR}_{\mathrm{CK}}=0.20 \mathrm{~h}^{-1}, \\
& \mathrm{TER}=0.014 \mathrm{~h}^{-1} \text { and } \mathrm{ERR}=0.018 \mathrm{~h}^{-1} .
\end{aligned}
$$

If the first plasma sample was obtained within 3 hours after the onset of symptoms, the corresponding enzyme activities were used for $\mathrm{C}_{\mathrm{s}}$. In the remaining cases, fixed mean values of $100 \mathrm{U} / 1$ and $112 \mathrm{U} / 1$ were used for creatine kinase and hydroxybutyrate dehydrogenase, respectively.

Calculation of cumulative release of myoglobin and fatty acid-binding protein into plasma

Intravenously injected radiolabelled myoglobin shows rapid initial disappearance from plasma with a half-life of $10-20 \mathrm{~min}(24,25)$. However, it is known that the process of radiolabelling may significantly alter the biophysical characteristics of myoglobin and may consequently disturb the estimation of the serum half-life. It was verified that the disappearance rate is not altered in patients with acute myocardial infarction (26). We used a two-compartment model for the calculation of the cumulative myoglobin and fatty acid-binding protein release. Using data on glomerular filtration rates in elderly adults (50-60 years) (27) and data on the extravasation and distribution of myoglobin $(28,29)$, parameter values obtained for fatty acid-binding protein (FABP) and myoglobin were: $\quad \mathrm{FCR}_{\text {myoglobin }}=2.1 \mathrm{~h}^{-1}, \quad \mathrm{FCR}_{\mathrm{FABP}}=2.1 \mathrm{~h}^{-1}, \quad$ TER $=0.3 \mathrm{~h}^{-1}$ and ERR $=0.1 \mathrm{~h}^{-1}$. The high FCR values for fatty acid-binding protein and myoglobin of course raise the question whether a one-compartment model, with extravasation neglected in comparison to clearance, would be sufficient for quantitative description of these proteins. However, as illustrated by the high value of TER $=0.3 \mathrm{~h}^{-1}$ for fatty acid-binding protein and myoglobin, versus TER $=0.014 \mathrm{~h}^{-1}$ for hydroxybutyrate dehydrogenase and creatine kinase, transcapillary exchange of these small proteins is also much larger than for the large enzyme molecules, and therefore has an appreciable influence, especially on early plasma kinetics. This prompted us to also use a two-compartment model for the small protein molecules. If the first plasma sample was obtained within 3 hours after the onset of symptoms, the corresponding concentrations were used for $C_{s}$. In the remaining cases, fixed mean values of $33 \mu \mathrm{g} / 1$ for myoglobin and $2 \mu \mathrm{g} / 1$ for fatty acid-binding protein were used. Samples with myoglobin concentrations below $50 \mu \mathrm{g} / \mathrm{l}$, the detection limit of the assay, were also indicated as $33 \mu \mathrm{g} / \mathrm{l}$, the mean reference value for myoglobin using a radioimmunoassay.

Expression of myocardial injury in gram-equivalents of tissue per liter of plasma

To express myocardial injury in gram-equivalents heart muscle per liter of plasma, the cumulative release of cardiac enzymes or proteins per litre of plasma was divided by the respective enzyme or protein content per gram wet weight of healthy myocardium. Creatine kinase, hydroxybutyrate dehydrogenase, fatty acid-binding protein and myoglobin contents per gram wet weight as determined in an earlier study of our group were respectively $2163 \mathrm{U} / \mathrm{g}, 156$ $\mathrm{U} / \mathrm{g}, 0.57 \mathrm{mg} / \mathrm{g}$ and $2.79 \mathrm{mg} / \mathrm{g}$ wet weight (16).

\section{Statistics and data presentation}

Release curves of proteins into plasma are presented as mean \pm SEM for the sake of clarity. Pearson's correlation coefficient was calculated to show relations between different parameters. A t-test for independent samples was used to assess statistically significant differences. The level of significance was set at $p<0.05$.

\section{Results}

\section{Mean concentration in plasma and}

\section{mean cumulative release}

Mean plasma concentrations or activities of the proteins examined as a function of time for all 20 patients (fig. 1a) showed a marked difference between the plasma kinetics of fatty acid-binding protein and myoglobin when compared to those of creatine kinase and hydroxybutyrate dehydrogenase. For both fatty acid-binding protein and myoglobin two peaks were seen in the mean plasma release curve. Within 24 hours the plasma concentration of both fatty acid-binding protein and myoglobin had returned to normal, whereas it took 50-70 hours for creatine kinase and more than 70 hours for hydroxybutyrate dehydrogenase.

The cumulative release patterns of the four proteins, expressed in gram equivalents of tissue per litre of plasma showed a large difference between fatty acid-binding protein and myoglobin compared to creatine kinase and hydroxybutyrate dehydrogenase (fig. lb). Release of fatty acid-binding protein and myoglobin were completed much earlier, but mean infarct size estimates obtained from myoglobin or fatty acid-binding protein 

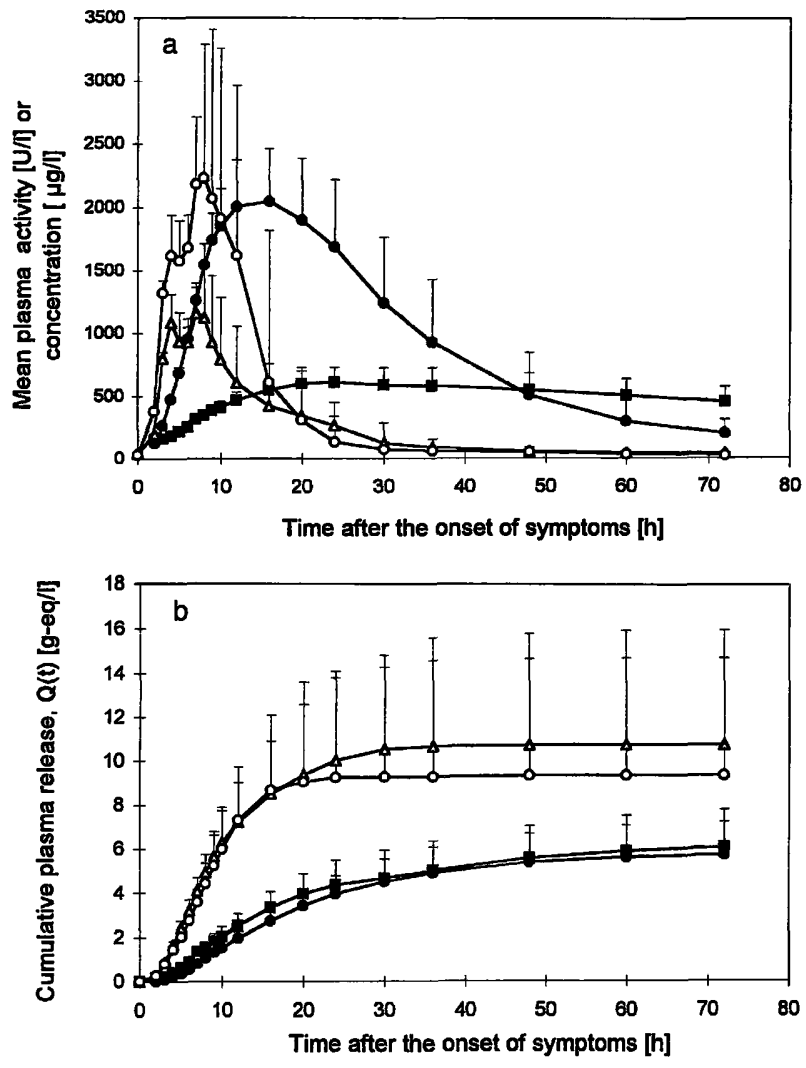

Fig. 1a, b Mean plasma concentrations or activities (a) and mean cumulative plasma release expressed in gram equivalents (g-eq) of healthy myocardium per litre plasma (b) of creatine kinase (๑) hydroxybutyrate dehydrogenase $(\square)$, myoglobin $(\Delta)$ and fatty acidbinding protein (multiplied by 10,0 ) as a function of time after the onset of symptoms, in 20 patients. Upper standard error of the mean (SEM) is indicated.

were almost twice the infarct size estimated from creatine kinase and hydroxybutyrate dehydrogenase plasma release curves.

As the low molecular mass proteins fatty acid-binding protein and myoglobin are eliminated from plasma by renal clearance, their plasma concentrations are influenced by changes in glomerular filtration rate. Therefore, the discordance between infarct size estimated from plasma creatine kinase or hydroxybutyrate dehydrogenase release, compared to infarct size estimated from plasma myoglobin or fatty acid-binding protein release might be caused by changes in renal function.

\section{Influence of renal function}

To examine the influence of possible changes or interindividual differences in renal function, plasma creatinine concentrations were measured in all plasma samples. Especially during the first hours after acute myocardial infarction, haemodynamic changes introduce variations in the plasma creatinine concentration. Therefore, the mean plasma creatinine concentration was estimated from plasma creatinine concentrations measured in all samples (9-12) taken during the first 24 hours after acute myocardial infarction. On the basis of the mean creatinine concentrations during the first 24 hours, the patients were divided into two groups (tab. 1). Patients with a mean creatinine concentration below the upper reference limit, below $110 \mu \mathrm{mol} / 1$ for men and 97 $\mu \mathrm{mol} / /$ for women, i. e. normal renal clearance (group 1) and patients whith a mean creatinine concentration above the upper reference limit for creatinine, abnormal renal clearance (group 2). Figure 2 shows the mean plasma creatinine concentrations as a function of time for these two patient groups.

The ratios between infarct size estimated from cumulative myoglobin or fatty acid-binding protein release and infarct size estimated from cumulative hydroxybutyrate dehydrogenase release $\left(\mathrm{Q}_{\text {myoglobin }} / \mathrm{Q}_{\mathrm{HBDH}}\right.$, fig. 3a or $\mathrm{Q}_{\mathrm{FABP}} / \mathrm{Q}_{\mathrm{HBDH}}$, fig. $3 \mathrm{~b}$ ), was found to be related to the mean creatinine concentration in samples taken during the first 24 hours after acute myocardial infarction. Thus, for patients with mean creatinine concentrations above the upper reference level, infarct sizes as determined from myoglobin or fatty acid-binding protein are severely overestimated. This appears to hold especially for the larger infarcts (tab. 1).

\section{Cumulative release of the different cardiac markers}

Mean cumulative release was again calculated after elimination of patients with mean creatinine concentrations above the upper reference limit of creatinine (group $2, \mathrm{n}=5$ ). Figure 4 shows the mean plasma creatine kinase and hydroxybutyrate dehydrogenase activities and the mean fatty acid-binding protein and myoglobin concentrations as a function of time in patients with normal renal function (group $1, \mathrm{n}=15$ ). After elimina-

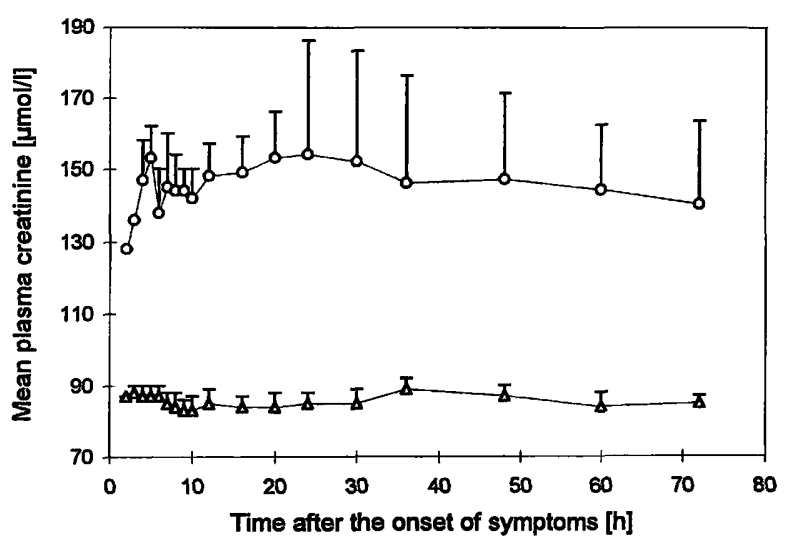

Fig. 2 Mean plasma creatinine concentrations as a function of time, for a group of patients $(n=15)$ with a mean creatinine concentration during the first 24 hours below the upper reference level $(\Delta)$ and for a group of patients $(n=5)$ with a mean creatinine concentration during the first 24 hours above the upper reference level (O). Upper standard error of the mean (SEM) is indicated. 

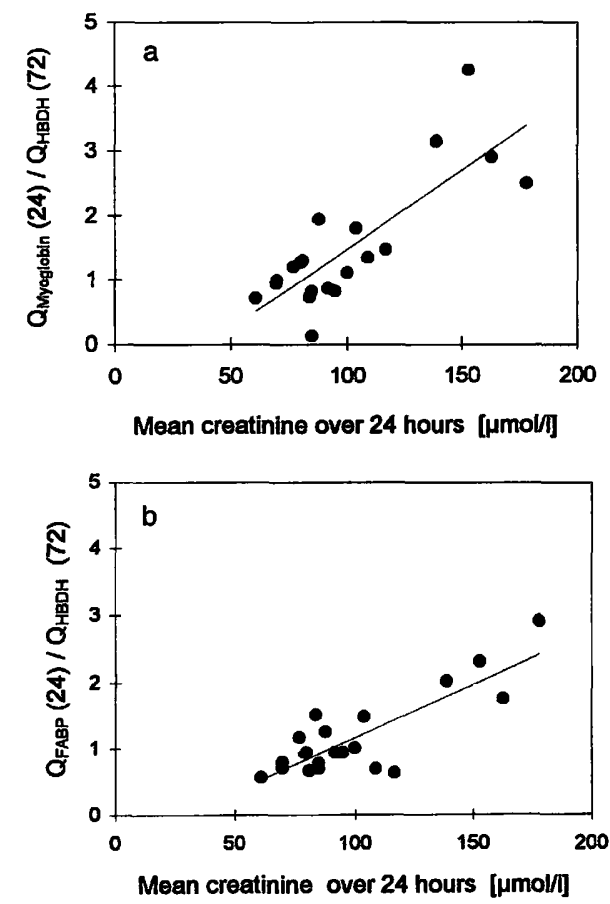

Fig. 3a, b Ratio of cumulative release of myoglobin or fatty acid binding protein (FABP) $Q(24)$ and cumulative release of hydroxybutyrate dehydrogenase (HBDH) $\mathrm{Q}(72)$ related to the mean creatinine concentration in the first 24 hours after the onset of symptoms (fig. $3 a, 3 b$ ) for 20 patients.

a. $\mathrm{y}=0.024 \mathrm{x}-0.98, \mathrm{r}=0.81$

b. $y=0.016 x-0.44, r=0.83$ tion of patients with an increased mean creatinine concentration during the first 24 hours after the onset of symptoms, cumulatively released quantities of creatine kinase, hydroxybutyrate dehydrogenase, fatty acid-binding protein and myoglobin amount to approximately similar estimates of infarct size. When expressed in $g$ eq of tissue per litre of plasma these figures became respectively $4.4,4.6,3.9$, and $4.8 \mathrm{~g}$-eq/I and were not significantly different.

\section{Correlation between infarct size calculated with different markers}

Correlations between infarct size calculated from plasma curves, using hydroxybutyrate dehydrogenase (HBDH) as a reference versus cumulative fatty acid-binding protein, cumulative myoglobin or cumulative creatine kinase (CK) are shown in figure 5 . The highest correlation was observed between $\mathrm{Q}_{\mathrm{HBDH}}$ and $\mathrm{Q}_{\mathrm{CK}}(\mathrm{r}=0.98)$. The relation between $\mathrm{Q}_{\mathrm{HBDH}}$ and $\mathrm{Q}_{\mathrm{CK}}$ was not disturbed by changes in renal function. A good correlation between $\mathrm{Q}_{\text {HBDH }}$ and $\mathrm{Q}_{\mathrm{FABP}}(\mathrm{r}=0.94)$ or $\mathrm{Q}_{\text {myoglobin }}(\mathrm{r}=0.92)$ was found only for patients with normal renal function (group $1, \mathrm{n}=15$ ), as estimated from plasma creatinine concentrations during the first 24 hours after acute myocardial infarction.

Tab. 1 Patient data

\begin{tabular}{|c|c|c|c|c|c|c|c|c|c|c|}
\hline Patient & Sex & $\begin{array}{l}\text { Age } \\
\text { (years) }\end{array}$ & $\begin{array}{l}\text { Treat- } \\
\text { ment } \\
\text { delay } \\
\text { (h) }\end{array}$ & $\begin{array}{l}\text { Mean } \\
\text { creat- } \\
\text { inine } \\
(\mu \mathrm{mol} / \mathrm{l})\end{array}$ & $\begin{array}{l}\mathrm{Q}_{\text {HвDH }}(72) \\
\text { (g-eq/l) }\end{array}$ & $\begin{array}{l}\mathrm{Q}_{\mathrm{CK}}(72) \\
\text { (g-eq/1) }\end{array}$ & $\begin{array}{l}\mathrm{Q}_{\mathrm{FABP}}(24) \\
\text { (g-eq/1) }\end{array}$ & $\begin{array}{l}Q_{\text {myoglobin }}(24) \\
\text { (g-eq/1) }\end{array}$ & $\begin{array}{l}\mathrm{Q}_{\text {myoglobin }}(24) / \\
\mathrm{Q}_{\text {HBDH }}(72)\end{array}$ & $\begin{array}{l}\mathrm{Q}_{\text {FABP }}(24) / \\
\mathrm{Q}_{\text {HBDH }}(72)\end{array}$ \\
\hline 1 & 우 & 55 & 1.8 & 85 & 1.66 & 0.12 & 1.3 & 0.19 & 0.11 & 0.78 \\
\hline 2 & $\hat{\sigma}$ & 78 & 1.8 & 109 & 1.43 & 1.52 & 0.99 & 1.9 & 1.33 & 0.69 \\
\hline 3 & $\hat{\sigma}$ & 55 & 2 & 61 & 4.3 & 5.14 & 2.43 & 3.02 & 0.70 & 0.57 \\
\hline 4 & $\hat{\sigma}$ & 55 & 1.9 & 81 & 7.01 & 6.15 & 4.69 & 9.02 & 1.29 & 0.67 \\
\hline 5 & $\hat{\sigma}$ & 59 & 1.8 & 77 & 3.64 & 3.99 & 4.24 & 4.34 & 1.19 & 1.16 \\
\hline 6 & $\hat{\sigma}$ & 54 & 4.5 & 85 & 14.08 & 14.82 & 9.89 & 11.4 & 0.81 & 0.70 \\
\hline 7 & 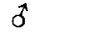 & 54 & 2.4 & 95 & 2.59 & 1.74 & 2.45 & 2.1 & 0.81 & 0.95 \\
\hline 8 & q & 62 & 0.7 & 70 & 3.19 & 2.68 & 2.53 & 3 & 0.94 & 0.79 \\
\hline 9 & $\hat{\sigma}$ & 60 & 1 & 70 & 9.61 & 9.7 & 6.78 & 9.39 & 0.98 & 0.71 \\
\hline 10 & 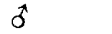 & 63 & 1.5 & 100 & 6.3 & 5.59 & 6.34 & 6.89 & 1.09 & 1.01 \\
\hline 11 & $\sigma$ & 49 & 1.3 & 92 & 2.75 & 1.07 & 2.6 & 2.36 & 0.86 & 0.95 \\
\hline 12 & $\hat{\sigma}$ & 59 & 3 & 80 & 6.38 & 6.85 & 5.97 & 8.02 & 1.25 & 0.94 \\
\hline 13 & $\tilde{\sigma}$ & 71 & 1 & 84 & 0.51 & 0.09 & 0.77 & 0.37 & 0.72 & 1.51 \\
\hline 14 & q & 61 & 0.8 & 88 & 2.06 & 3.4 & 2.59 & 3.97 & 1.92 & 1.26 \\
\hline 15 & $\tilde{\sigma}$ & 67 & 1.8 & 104 & 3.01 & 3.09 & 4.47 & 5.36 & 1.78 & 1.49 \\
\hline \multirow[t]{3}{*}{ Group 1: } & mean & 60.1 & 2.2 & 84 & 4.57 & 4.40 & 3.87 & 4.76 & 1.05 & 0.94 \\
\hline & & 7.5 & 1.0 & 13 & 3.60 & 3.94 & 2.54 & 3.46 & 0.44 & 0.29 \\
\hline & median & 59 & 2.0 & 85 & 3.19 & 3.4 & 2.6 & 3.97 & 0.98 & 0.94 \\
\hline 16 & $\tilde{\sigma}$ & 55 & 1.8 & 117 & 6.79 & 7.3 & 4.29 & 9.88 & 1.46 & 0.63 \\
\hline 17 & $\hat{\sigma}$ & 63 & 5.3 & 178 & 35.5 & 29.1 & 103.0 & 87.7 & 2.47 & 2.90 \\
\hline 18 & $\bar{\sigma}$ & 50 & 4 & 153 & 1.47 & 1.83 & 3.38 & 6.21 & 4.22 & 2.30 \\
\hline 19 & 3 & 65 & 1.8 & 139 & 7.79 & 9.09 & 15.66 & 24.26 & 3.11 & 2.01 \\
\hline 20 & $\hat{\sigma}$ & 74 & 1.8 & 163 & 0.16 & 0.05 & 0.28 & 0.46 & 2.88 & 1.75 \\
\hline \multirow[t]{3}{*}{ Group 2: } & mean & 61.4 & 2.9 & 150 & 10.34 & 9.47 & 25.33 & 25.70 & 2.83 & 1.92 \\
\hline & SD & 9.3 & 1.6 & 23 & 14.44 & 11.59 & 43.83 & 35.75 & 1.00 & 0.84 \\
\hline & median & 63 & 1.8 & 153 & 6.79 & 7.3 & 4.29 & 9.88 & 2.88 & 2.01 \\
\hline
\end{tabular}



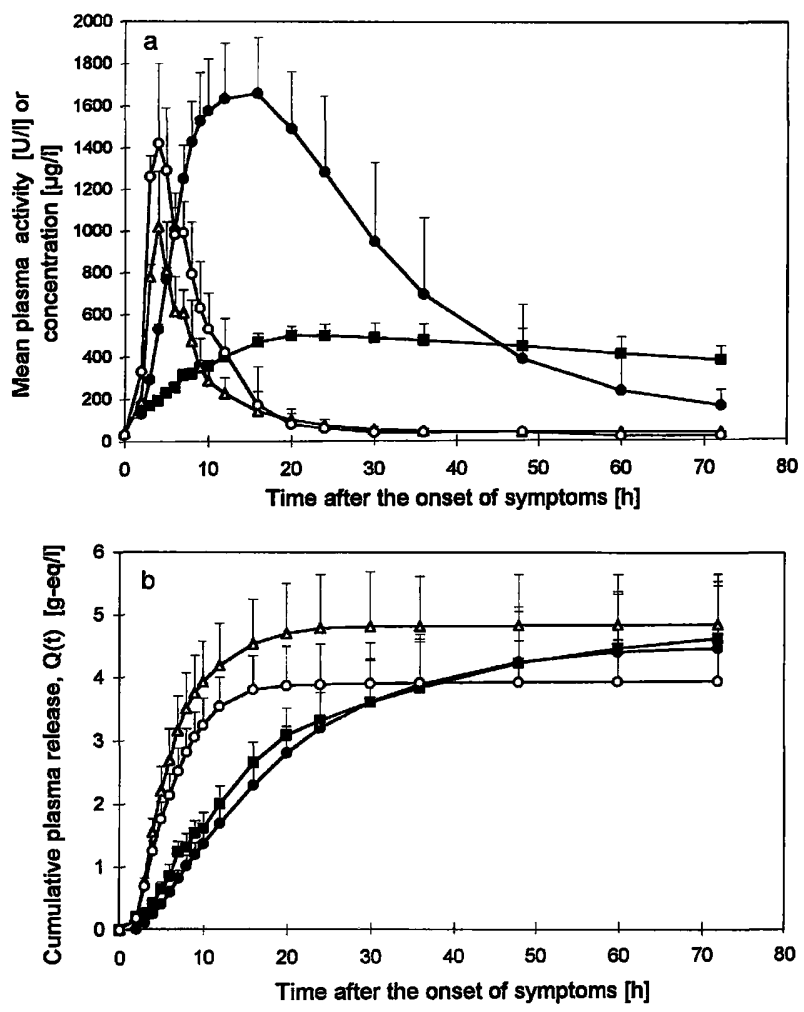

Fig. 4a, b Mean plasma concentrations or activities (a) and mean cumulative release expressed in gram equivalents (g-eq) of healthy myocardium per litre plasma (b) of creatine kinase ( $\bullet$ ), hydroxybutyrate dehydrogenase $(\boldsymbol{\nabla})$, myoglobin $(\Delta)$ and fatty acid-binding protein (multiplied by 10,0 ) as function of time after onset of symptoms, in 15 patients with normal renal function as based on mean creatinine concentration during the first 24 hours after acute myocardial infarction. Upper standard error of the mean (SEM) is indicated.

\section{Discussion}

Quantitation of infarct size from serial plasma myoglobin on fatty acid-binding protein concentrations

Size estimation of myocardial infarction from serial serum myoglobin concentrations was first performed by Groth et al. (30). In that study a reasonable correlation $(r=0.72)$ was found between the myoglobin estimates of infarct size compared to the creatine kinase-MB estimates of infarct size. Grottum et al. found a reasonable correlation $(r=0.72)$ between infarct size estimates from creatine kinase and myoglobin plasma curves (31). The authors suggested myoglobin as an early marker for estimation of infarct size, because creatine kinase release starts 3-5 hours after acute myocardial infarction, whereas myoglobin release generally starts earlier and is already completed within $24 \mathrm{~h}$ after acute myocardial infarction. In both studies infarct size was not expressed in gram equivalents of healthy myocardium per litre plasma (g-eq/l) and therefore quantitative comparison of infarct size measures obtained with creatine kinase, creatine kinase-MB and myoglobin was not possible.
In the present study infarct size, estimated from plasma curves of different cardiac markers was expressed in gram equivalents of healthy cardiac tissue, using cardiac tissue contents estimated in an earlier study (16). This allowed us to quantitatively compare the infarct size measures obtained with the different cardiac markers. We compared infarct size estimates obtained from plasma release curves of low molecular mass markers like myoglobin or fatty acid-binding protein, with infarct size estimates obtained with the established infarct size markers creatine kinase and hydroxybutyrate dehydrogenase.

\section{Sources of error in infarct size estimation \\ Influence of renal function on estimation of infarct size}

The plasma release curves of myoglobin and fatty acidbinding protein showed a completely similar pattern and suggest that both myoglobin and fatty acid-binding protein are released from the heart and cleared from the blood-
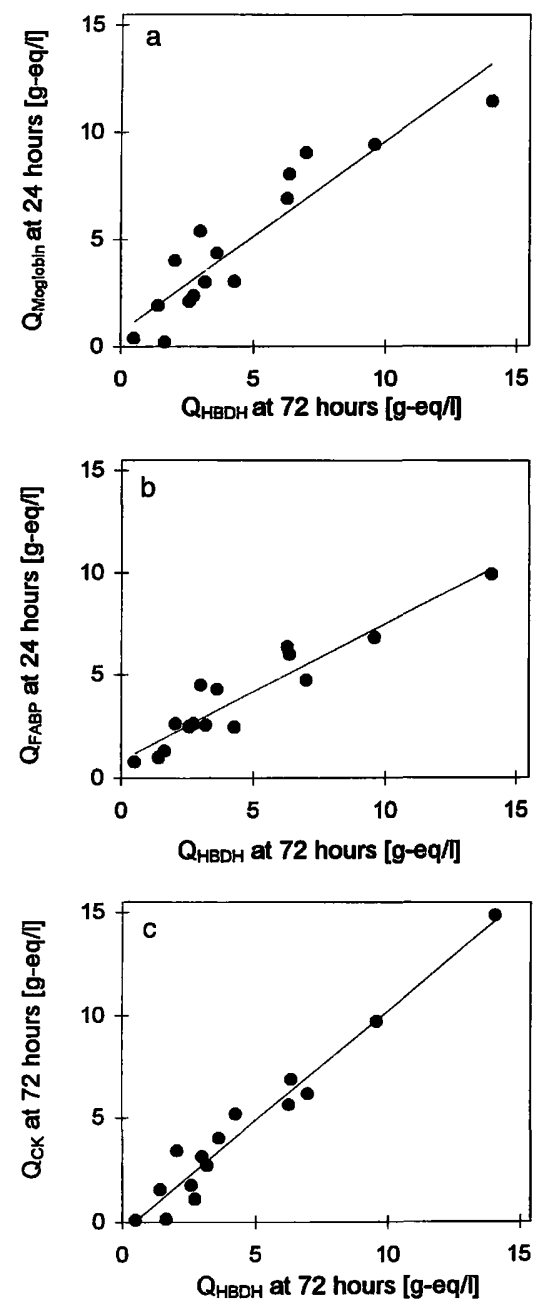

Fig. 5 Correlation between cumulative hydroxybutyrate dehydrogenase (HBDH) release and cumulative myoglobin- (a), fatty acid binding protein (FABP)- (b) or creatine kinase (CK)-release (c) in patients with normal renal function, $n=15$. The calculated regression lines are:

a. $\mathrm{y}=0.88 \mathrm{x}+0.72, \mathrm{r}=0.92$

b. $y=0.66 x+0.84, r=0.94$

c. $\mathrm{y}=1.07 \mathrm{x}-0.48, \mathrm{r}=0.98$ 
stream essentially in the same manner. In view of their low molecular masses, it is most likely that myoglobin $\left(M_{\mathrm{r}}\right.$ $18000)$ as well as fatty acid-binding protein $\left(M_{\mathrm{r}} 15000\right)$ are eliminated from the circulation mainly by renal clearance $(2,32)$. Indeed, both proteins have been found in urine from patients with acute myocardial infarction $(9$, $10,33)$. For myoglobin, it has been demonstrated that plasma concentrations are inversely related to the glomerular filtration rate and linearly related to the serum creatinine concentration in 68 patients with renal disease (17). For fatty acid-binding protein elevated plasma levels have also been found in the case of renal insufficiency $(14,18)$.

Acute myocardial infarction induces activation of many neurohormonal mechanisms, which all have direct influences on renal haemodynamics and excretory function. It has been demonstrated that in patients with untreated acute myocardial infarction, glomerular filtration rate was initially high and decreased from day 2 to day 10 (118 vs. $104 \mathrm{ml} / \mathrm{min}$ ) (34). Comparable results were found in an earlier study where ${ }^{51} \mathrm{Cr}$-EDTA clearance was measured in 10 patients immediately after acute myocardial infarction and three weeks later (35). This implies that individual differences in renal clearance of these low molecular mass proteins will cause error in calculated infarct size. We measured plasma creatinine in all samples taken during the first 72 hours after acute myocardial infarction. Due to haemodynamic and plasma volume changes during the first hours after the onset of symptoms, considerable intra-individual variation in plasma creatinine concentration can occur. As cumulative fatty acid-binding protein and myoglobin release were completed within 24 hours (see fig. $1 \mathrm{~b}$ and fig. 4b), mean plasma creatinine was calculated from samples taken during the first 24 hours only. We found a relation between mean plasma creatinine during the first 24 hours after acute myocardial infarction and the discordance between infarct size estimated from low molecular mass cardiac markers fatty acid-binding protein and myoglobin, as compared to the high molecular mass marker hydroxybutyrate dehydrogenase.

For patients with normal mean creatinine concentrations during the first 24 hours after acute myocardial infarction there is a good correlation between infarct size estimated from plasma myoglobin or fatty acid-binding protein release and infarct size estimated with the established infarct size marker hydroxybutyrate dehydrogenase. For patients with increased creatinine concentrations, estimation of infarct size from plasma myoglobin or fatty acid-binding protein curves can be severely overestimated (especially for larger infarcts).

Serum creatinine alone is of course not the ideal marker to express renal function, but it appeared sufficient to eliminate patients with severe disturbance of glomerular filtration. As we did not measure body weight of the individual patients, we were not able to make a more precise estimate of creatinine clearance. It is to be expected that the correlation between creatine clearance and cumulative fatty acid-binding protein or myoglobin release will be even stronger than it is with mean serum creatinine concentration.

\section{Sampling scheme}

It has been shown that plasma myoglobin levels after acute myocardial infarction behave rather erraticly, the so-called staccato phenomenon (36). For a frequent sampling schedule, the isolated "spikes" will contribute little to the curve area and will tend to cancel. As the sampling becomes sparser, however, an accidental high or low value may introduce considerable error and this effect could be enhanced in patients treated with thrombolytic therapy, because of the accelerated release observed after such therapy. Therefore, accurate quantification of infarct size from plasma myoglobin or fatty acid-binding protein curves is more reliable from frequently sampled plasma curves.

\section{Variation in cardiac tissue content}

The variation in myocardial myoglobin content is about $25 \%$ and is larger than the values of about $15 \%$ found for fatty acid-binding protein and hydroxybutyrate dehydrogenase (16). In the present study the scatter of infarct size calculated from plasma myoglobin or fatty acidbinding protein curves, compared to infarct size estimated from plasma hydroxybutyrate dehydrogenase curves was comparable.

\section{Complete recovery of myoglobin and fatty acid-binding protein}

Quantitative recovery of cytoplasmic proteins in plasma after ischaemic myocardial damage has been demonstrated in experimental studies. The total quantity of myoglobin depleted from dog heart after 2 hours of coronary occlusion (37), and the total activities of creatine kinase and hydroxybutyrate dehydrogenase depleted from dog heart after permanent occlusion (38), equalled the calculated release of these proteins in plasma. The similarity of estimates of injury for the different cardiac markers, shown in figure $4 \mathrm{~b}$, supports these demonstrations of complete recovery. Incomplete recovery could only be compatible with the results shown in figure $4 \mathrm{~b}$ if infarcted domains existed in which all proteins remain confined and are totally prevented from reaching the circulation.

In summary, the present study shows that estimation of infarct size from serial plasma myoglobin or fatty acidbinding protein concentrations is possible in the first 24 hours after the onset of symptoms, but only in patients with normal plasma creatinine concentrations during this period. For these patients a good agreement was found 
between infarct size estimated from the cumulative plasma hydroxybutyrate dehydrogenase release and in-

\section{References}

1. Hearse D. Molecular enzyme release. J Mol Med 1977; $2: 185-200$

2. Kagen L. Myoglobin: methods and diagnostic uses. CRC Crit Rev Lab Sci 1978; 9:273-302.

3. Cairns J, Missirlis E, Walker W. Usefulness of serial determinations of myoglobin and creatinine kinase in serum compared for assessment of acute myocardial infarction. Clin Chem $1983 ; 29: 469-73$

4. Delanghe J, DeBuyzere M, Cluyse L, Thierens H, Clement D. Acute myocardial infarction size and myoglobin release into serum. Eur J Clin Chem Clin Biochem 1992; 30:823-30.

5. Mair J, Artner-Dworzak E, Lechleiter P, Morass B, Smidt J, Wagner I, et al. Early diagnosis of acute myocardial infarction by a newly developed rapid immunoturbidimetric assay for myoglobin. Br Heart J 1992; 68:462-8.

6. Ellis K, Little T, Masud Z, Liberman H, Morris D, Klocke F. Early non-invasive detection of successful reperfusion in patients with acute myocardial infarction. $1.1988 ; 78: 1352-7$.

7. Katus HA, Diederich K, Scheffold T, Uellner M, Schwarz F, Kubler W. Non-invasive assessment of infarct reperfusion: the predictive power of time to peak value of myoglobin, CKMB and CK in serum. Eur Heart J 1988; 619-24.

8. Yamashita T, Abe S, Arima S, Nomoto K, Miyata M, Maruyama I, et al. Myocardial infarct size can be estimated from serial plasma myoglobin measurements within 4 hours of reperfusion. Circulation 1993; 87:1840-9.

9. Tanaka T, Hirota $Y$, Sohmiya $K$, Nishimura S, Kawamura $K$. Serum and urinary heart fatty acid binding protein in acute myocardial infarction. Clin Biochem 1991; 24:195-201.

10. Kleine A, Glatz J, Van Nieuwenhoven F, Van der Vusse G. Release of fatty-acid binding protein into plasma after acute myocardial infarction in man. Mol Cell Biochem 1992; 116:155-62.

11. Glatz J, Kleine A, Van Nieuwenhoven F, Hermens WT, Van Dieijen-Visser M, Van der Vusse G. Fatty-acid-binding protein as a plasma marker for the estimation of myocardial infarct size in humans. Br Heart $\mathrm{J} 1994 ; 71: 135-40$.

12. Glatz J, Van der Vusse G. Cellular fatty acid binding proteins: current concepts and future directions. Mol Cell Biochem 1990; 98:237-51.

13. Glatz J, Van der Vusse G. Cellular fatty acid-binding proteins: their function and physiological significance. Progress in Lipid Research 1996. In press.

14. Van Nieuwenhoven F, Kleine A, Wodzig K, Hermens W, Kragten $\mathrm{H}$, Maessen $\mathrm{J}$, et al. Discrimination between myocardial and skeletal muscle injury by assessment of the plasma ratio of myoglobin over fatty acid-binding protein. Circulation 1995; 92:2848-54.

15. Yoshimoto K, Tanaka T, Somiya K, Tsuji R, Okamoto F, Kawamura $\mathrm{K}$, et al. Human heart-type cytoplasmic fatty acidbinding protein as an indicator of acute myocardial infarction. Heart Vessels 1995; 10:304-9.

16. Kragten J, Van Nieuwenhoven F, Van Dieijen-Visser M, Theunissen P, Hermens W, Glatz J. Distribution of myoglobin and fatty acid binding protein in human cardiac autopsies. Clin Chem 1996; 42:337-8.

17. Hallgren R, Karlsson F, Roxin L, Venge P. Myoglobin turnover, influence of renal and extrarenal factors. J Lab Clin Med 1978; 91:246-54.

18. Gorski J, Hermens W, Borawski J, Mysliwiec M, Glatz J. Fatty acid-binding protein concentration of patients with chronic renal failure is elevated. Clin Chem 1996. In press.

19. Delanghe J, Chapelle J, Magdeleine E, DeBuyzere M. Quantitative turbidimetric assay for determining myoglobin evaluated. Ann Clin Biochem 1991; 28:474-9.

20. Wodzig K, Pelsers M, Van der Vusse G, Roos W, Glatz J. One-step enzyme-linked immunosorbent assay (ELISA) for farct size estimated from the cumulative myoglobin or fatty acid-binding protein release.

plasma fatty acid-binding protein. Ann Clin Biochem 1996. In press.

21. Visser M, Krill M, Willems G, Hermens W. Selection of a suitable model for the plasma clearance and distribution of cardiac enzymes in the dog. Cardiovasc Res 1981; 15:35-42.

22. Van Kreel B, Van der Veen, Willems G, Hermens W. Circulatory models in assessment of cardiac enzyme release in dogs. Am J Physiol 1993; (Heart Circ Vol 33): H747-54.

23. Willems G, Visser M, Krill M, Hermens W. Quantitative analysis of plasma enzyme levels based on simultaneous determination of different enzymes. Cardiovasc Res 1982; 16: 120-31.

24. Koskelo P, Kekki M, Wager O. Kinetic behavior of 131I-labeled myoglobin in human beings. Clin Chim Acta 1967; 17:339-47.

25. Sylven $C$. The kinetics of myoglobin in old volunteers and in patients with acute myocardial infarction. Scand J Clin Lab Invest $1989 ; 38: 561-5$.

26. Groth T, Sylven C. Myoglobin kinetics in patients suffering from acute myocardial infarction in its early phase - as studied by the single injection method. Scand J Clin Lab Invest $1981 ; 44: 65-78$.

27. Geigy. Wissenschaftliche Tabellen, Körperflüssigkeiten 8. Basel, 1977.

28. Renkin E. Multiple pathways of capillary permeability. Circ Res 1977; 41:435-43.

29. Renkin E, Curry F. Transport of water and solutes across capillary endothelium. In: Giebisch G, Tosteson DC, Ussing HH, editors. Membrane transport in biology. Berlin: Springer Verlag 1979:1-45.

30. Groth T, Hakman M, Sylven C. Size estimation of acute myocardial infarction from serial serum myoglobin observations with due consideration of individual differences in basic kinetics. Scan J Clin Lab Invest 1984; 44:65-78.

31. Grottum P, Sederholm M, Kjekshus J. Quantitative and temporal relation between the release of myoglobin and creatine kinase and the evolution of vectorcardiographic changes during acute myocardial infarction in man. Cardiovasc Res 1987; 21:652-9.

32. Rabkin R, Dahl D. Renal uptake and disposal of proteins and peptides. New York: Plenum Press, 1993.

33. Fsuji R, Tanaka $T$, Sohmiya $K$, Nishimura S, Kawamura $K$. Human heart-type cytoplasmic fatty acid-binding protein as an indicator of acute myocardial infarction. Int J Cardiol 1993; 41:209-17.

34. Abildgaard U, Andersen J, Daugaard G, Aldershville J, Nielsen $\mathrm{S}$, Christensen $\mathrm{N}$, et al. Renal function in patients with untreated acute myocardial infarction. Scand J Clin Lab Invest 1992; 52:689-5.

35. Efendigil M, Harley A, Deegan T, McKendrick C. Changes in glomerular filtration rate following myocardial infarction. Cardiovascular Research 1975; 9:741-4.

36. Kagen L, Scheidt S, Butt A. Serum myoglobin in myocardial infarction. The "staccato phenomenon". Am J Med 1977; 62:86-92.

37. Ellis A, Saran B. Kinetics of myoglobin release and prediction of myocardial depletion after coronary artery reperfusion. Circulation $1989 ; 80: 676-83$.

38. Hermens W, Van der Veen F, Willems G, Mullers-Bouman M, Schrijvers-van Schendel A, Reneman R. Complete recovery in plasma of enzymes lost from the heart after permanent coronary occlusion in the dog. Circulation 1990; 81:649-59.

\section{Received November 7, 1996/January 6, 1997}

Corresponding author: Prof. dr. M. P. van Dieijen-Visser, Department of Clinical Chemistry, Academic Hospital Maastricht, P. O. Box 5800, NL-6202 AZ Maastricht, The Netherlands 